\title{
不連続特性を有する構造システムの設計感度解析と最適設計 DESIGN SENSITIVITY ANALYSIS AND OPTIMIZATION OF STRUCTURAL SYSTEMS WITH DISCONTINUOUS PROPERTIES
}

\author{
大崎＼cjkstart純* \\ Makoto OHSAKI
}

\begin{abstract}
An incremental approach is presented for design sensitivity analysis of structural systems with discontinuous properties. In the proposed approach, the transition time, at which the governing equations change discontinuously, is considered as a function of the design variables. The incremental response analysis and design sensitivity analysis are carried out simultaneously. Newton-Raphson type incremental and iterative approach is presented for systems with geometrical nonlinearity. Efficiency of the proposed method is demonstrared in the examples of a contact problem of a truss and elasto-plastic structures subjected to cyclic loading conditions.
\end{abstract}

Keywords : discontinuous property, sensitivity analysis optimum design, contact problem, elasto-plastic structure, geometrical nonlinearity

不連続特性, 感度解析, 最適設計, 接触問題, 弾塑性構造物, 幾何学的非線形性

1. 序

設計感度解析法は, 部材断面積等の設計変数の変化 にともなう応答量の変化率 (設計感度係数) を求める手 法であり, 最適設計法, 逆問題型設計法, 構造同定法等 の基碟的役割を果たす手法である。さらに，設計感度係 数は，それ自身，設計変更の過程において，設計者に対 する有意義な情報となるものである。構造システムの設 計感度解析法及び最適設計法に関する従来の研究のほと んどは，弾性構造物等の，システムのあらゆる状態にお いてその特性が 1 組の方程式系で支配されるような系を 取り扱ったものである ${ }^{1-3}$ 。ところで, 構造システムの 応答解析問題には, 弾塑性応答解析問題, 接触問題 ${ }^{4}$, 片側応力問題 ${ }^{5}$ 等の, システムの特性を決定する支配方 程式の成立範囲が, 変位, 応力等の状態量に関する不等 式で定められる問題が多く存在する。

弾塑性構造物の設計感度解析法及び最適設計法に関 する初期の論文 ${ }^{6-9}$ では, 幾何学的非線形性及び応答量 の履歴依存性は考慮されていない。また，最近の論文 10-13でも，履歴依存性は簃密には考慮されていない。 境界条件が変分不等式で与えられる構造物の感度解析法 及び最適設計法に関する論文 ${ }^{14,15}$ では, 境界条件が載
荷にともない変化するような接触問題については論じら れていない。それに対し，著者らは，繰り返し載荷を受 ける弾塑性構造物に対し, 応力 -ひずみ関係の接線俰数 が不連続に変化することを厳密に考慮した設計感度解析 法を開発した ${ }^{16}$ 。

建築構造物の設計においては, 力学的条件以外に も，建築計画，施工等に関わる種々の制約条件が考慮さ れる。本論では, 手法の簡単な説明のため, 構造設計の みを取り扱い，制約条件には力学的条件を考虑して，目 的関数には全構造コストを与える。本論で展開する一般 的定式化を用いれば，他の要因についても定式化可能な 範囲で容易に導入することができる。また，「最適設計 問題」(optimum design problem)は, $1 つ の$ 数理計 画問題として定式化できるような設計問題を意味する。 さらに，「構造システム」(structural system)は, い くつかの要素が結合してある力学的条件下で要求される 目的を達成する系という意味で用いる ${ }^{17}$ 。

本論では, 文献 16 の手法を一般化して, 種々の不連 続特性を有する構造システムに対して適用可能な一般的 設計感度解析法を提示し，接触問題のプロトタイプとし ての変位拘束を有するトラス及び，繰り返し載荷を受け

* 京都大学工学部建築学教室 助手. 博士 (工学) Research Assoc., Dept. of Architecture, Faculty of Engineering, Kyoto Univ., Dr. Eng. 
る弾塑性構造物に対して適用することによりその有効性 を明らかにする。また，汎用最適化プログラムを用いて 最適設計解を求め, 幾何学的非線形性の最適設計解に及 ほす影響について考察する。

\section{2. 不連続特性を有する構造システムの応答解析}

有限要素法を用いて離散化された構造システムを考 える。応力ーひずみ関係の接線係数等のシステムの特性 量が変位等の状態変数 (state variable) の不連続関数で ある場合，その応答量を求めるためには増分応答解析を 行なわなければならない。いま,簡単のため, 荷重べク トル $\boldsymbol{P}(t)$ が載荷パラメター (時刻) $t$ の関数である荷重 保数 $\alpha(t)$ を用いて

$$
\boldsymbol{P}(t)=\alpha(t) \boldsymbol{P}^{0}
$$

のように表わされる場合を考える。ここで， $P^{0}$ は与え られた基準べクトルである。要素の断面皘等の設計変数 ベクトルを $\boldsymbol{A}$ とする。以後簡単のため, 設計変数 $\boldsymbol{A}$ で 定義されるシステムを設計 $\boldsymbol{A}$ とよぶ。システムの釣合 い状態が

$$
\boldsymbol{F}(\boldsymbol{u}(t, \boldsymbol{A}), \boldsymbol{A})=\boldsymbol{P}(t)
$$

で表わされるものとする。ここで， $u(t, A)$ は変位べク トルであり， $\boldsymbol{F}$ は設計 $\boldsymbol{A}$ の時刻 $t$ に扔ける内力と等価 な節点力ベクトルである。

第 $i$ 列が $\frac{\partial \boldsymbol{F}}{\partial u_{i}}$ である行列を $K$ とすると， $K$ は接線 剛性行列とよばれる 18 。このとき，(1)を用いると，

(2)の速度型表現は次のようになる。

$$
\boldsymbol{K}(t, \boldsymbol{A}) \dot{\boldsymbol{u}}(t, \boldsymbol{A})=\dot{\alpha}(t) \boldsymbol{P}^{0}
$$

ここで，(）は $t$ に関する微分である。

初期状態に扔いて，(2)によって釣合い状態が決定 されるための不等式条件が全て不等号で満たされている ものとする。その条件は, 弾塑性構造物では降伏条件, 片側応力問題では応力あるいはひずみの符号が变化しな い条件であり，接触問題では変位の拘束条件である。こ こでは, 簡単のため,

$$
\boldsymbol{G}(\boldsymbol{u}(t, \boldsymbol{A})) \leq \mathbf{0}
$$

のような $u$ に関する条件が与えられるものとする。 $\boldsymbol{G}$ が応力あるいはひずみの関数である場合にも同様の定式 化が可能である。

$t$ を増加させたとき，(4)の $1 つ G_{j} \leq 0$ が $t=t^{(j)}$ で等号で満たされ，以後 $G_{j}=0$ が成立するものとす る。また, さらに $t$ を増加させると $t=t^{(j+1)}$ で条件 $G_{j+1} \leq 0$ が等号で満たされるものとする。すなわち $t^{(j)}$ 及び $t^{(j+1)}$ は

$$
\begin{aligned}
& G_{j}\left(\boldsymbol{u}\left(t^{(j)}, \boldsymbol{A}\right)\right)=0, \\
& G_{j+1}\left(\boldsymbol{u}\left(t^{(j+1)}, \boldsymbol{A}\right)\right)=0
\end{aligned}
$$

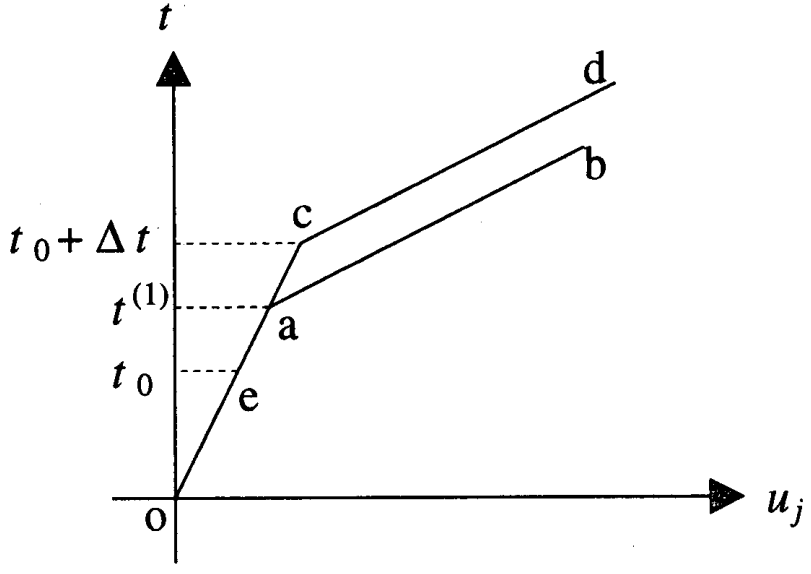

図-1 載荷パラメター (時刻) と変位の関係

で求められる。簡単のため $t^{(j)}, t^{(j+1)}$ 等を境界時間と よぷ。

いま, $\boldsymbol{K}(t, \boldsymbol{A})$ は $t$ の不連続な関数であり，区間 $t^{(j)} \leq t \leq t^{(j+1)}$ において一定值 $\boldsymbol{K}^{(j)}(\boldsymbol{A})$ をとるもの とする。さらに，区間 $t^{(j)} \leq t \leq t^{(j+1)} に$ において $\dot{\alpha}(t)$ は一定值 $\dot{\alpha}^{(j)}$ をとるものとする。本節では，本論で提 示する手法の特長を 3 節で述べるための準備として, $K$ が $t$ に関して区分的に一定值をとる場合を考える。 $t$ の各区間において $\boldsymbol{K}$ が $\boldsymbol{u}$ に依存する場合，すなわち幾 何学的非線形性を考慮する場合については，4節で詳し く述べる。このとき，

$$
\boldsymbol{u}^{(j)}(\boldsymbol{A})=\boldsymbol{u}\left(t^{(j)}, \boldsymbol{A}\right)
$$

等の記号を用いると，(3)より次の増分型表現を得る。

$$
\begin{gathered}
\boldsymbol{K}^{(j)}(\boldsymbol{A})\left\{\boldsymbol{u}^{(j+1)}(\boldsymbol{A})-\boldsymbol{u}^{(j)}(\boldsymbol{A})\right\} \\
=\left(t^{(j+1)}-t^{(j)}\right) \dot{\alpha}^{(j)} \boldsymbol{P}^{0}
\end{gathered}
$$

$t^{(j)}, \dot{\alpha}^{(j)}, \boldsymbol{K}^{(j)}$ 及び $\boldsymbol{u}^{(j)}(\boldsymbol{A})$ が既知であるとき， (7) より $\boldsymbol{u}^{(j+1)}(\boldsymbol{A})$ は

$$
\boldsymbol{u}^{(j+1)}(\boldsymbol{A})=\boldsymbol{d}_{1}^{0} t^{(j+1)}+\boldsymbol{d}_{2}^{0}
$$

のような形で表現できる。ここで， $\boldsymbol{d}_{1}^{0}, \boldsymbol{d}_{2}^{0}$ は既知べク トルである。(8)を $(5 b)$ に代入することにより $t^{(j+1)}$ が得られ，これを再び $(8)$ に用いると $\boldsymbol{u}^{(j+1)}(\boldsymbol{A})$ を求 めることができる。

$t=t_{1}^{(j)}\left(t^{(j)}<t_{1}^{(j)}<t^{(j+1)}\right)$ に扔いて $\dot{\alpha}(t)$ が不連 続に変化するときには， $\dot{\alpha}(t)=\alpha_{1}^{(j)}\left(t^{(j)} \leq t \leq t_{1}^{(j)}\right)$, $\dot{\alpha}(t)=\alpha_{2}^{(j)}\left(t_{1}^{(j)} \leq t \leq t^{(j+1)}\right)$ とすると,

$$
\begin{aligned}
& \boldsymbol{K}^{(j)}(\boldsymbol{A})\left\{\boldsymbol{u}\left(t_{1}^{(j)}, \boldsymbol{A}\right)-\boldsymbol{u}^{(j)}(\boldsymbol{A})\right\} \\
& \quad=\left(t_{1}^{(j)}-t^{(j)}\right) \dot{\alpha}_{1}^{(j)} \boldsymbol{P}^{0} \\
& \boldsymbol{K}^{(j)}(\boldsymbol{A})\left\{\boldsymbol{u}^{(j+1)}(\boldsymbol{A})-\boldsymbol{u}\left(t_{1}^{(j)}, \boldsymbol{A}\right)\right\} \\
& =\left(t^{(j+1)}-t_{1}^{(j)}\right) \dot{\alpha}_{2}^{(j)} \boldsymbol{P}^{0}
\end{aligned}
$$

が成立する。 $t_{1}^{(j)}$ は載荷条件により定められる指定値 であるから，(9a)より $\boldsymbol{u}\left(t_{1}^{(j)}, \boldsymbol{A}\right)$ が得られ，(9b)及び 
$(5 b)$ を用いて $t^{(j+1)}$ 及び $u^{(j+1)}(A)$ を求めることがで きる。 $t^{(j)}<t<t^{(j+1)}$ に扔いて複数の時刻で $\dot{\alpha}(t)$ が 不連続に変化する場合も同様である。

$t$ と $u_{j}$ の関係が図 1 の折線状経路 oab ゙表わされる ようなシステムを考える。 $t$ を 0 から增加させたとき $t=t^{(1)}$ で点 $\mathrm{a}$ に達し，接線剛性行列は不連続に変化す る。最も単純な増分応答解析法としては， $t$ の一定増分 $\Delta t$ を与える方法が考えられる。このとき， $t$ を $t_{0}$ から $\Delta t$ 増加させると, 経路上の点 $\mathrm{e}$ から $\mathrm{c}$ に移動する。点 $\mathrm{c}$ は正解の経路 $\mathrm{oab}$ 上に存在しないから, 点 $\mathrm{c}$ で接線剛 性行列を変更してもそれ以後の経路は cdのようにな り，正確な応答量を得ることができない。したがって， 精度の良い応答值を得るためには，境界時間を正確に求 めることが必要である。

\section{3. 最適設計問題及び設計感度解析法}

変位, 応力, ひずみ等の応答量の絶対値の最大值を 表わすべクトルを $H(A)$ とし， $H(A)$ に対する指定上 限值のベクトルを $\overline{\boldsymbol{H}}$ とする。コスト関数を $C(\boldsymbol{A})$ と し，次のような最適設計問題を考える。

[構造システムの最適設計問題] 最大応答量に関する 制約条件 $\boldsymbol{H}(\boldsymbol{A}) \leq \overline{\boldsymbol{H}}$ の下で，全コスト $C(\boldsymbol{A})$ を最小 とするような最適設計解を求めよ。

ここでは，簡単のため，応答量の最大值に関する制 約条件のみ考慮したが， $t$ の関数の形式での制約条件を 指定することも可能である。この最適設計問題に対する 最適設計解を数理計画法の何らかの手法を用いて求める ためには， $\boldsymbol{H}(\boldsymbol{A})$ の $\boldsymbol{A}$ に関する感度係数が得られなけ ればならない。

最大応答量の設計感度係数を求める際に，境界時間 の感度係数を求めることの必要性について考察するた め, 設計 $\boldsymbol{A}=\boldsymbol{A}_{0}$ の $t$ と $u_{j}$ の関係が図 2 の折線状経路 oabで表わされるようなシステムを考える。簡単のた め, $u_{j}=u_{j}^{(1)}$ で接線剛性行列が不連続に変化するもの とする。設計 $\boldsymbol{A}_{0}$ において,$u_{j}=u_{j}^{(1)}$ が成立する $t$ の 值を $t_{0}^{(1)}$ とする。 $\boldsymbol{A}_{0}$ から設計変数べクトルを微小量 $\Delta \boldsymbol{A}$ 変化させた設計 $A_{0}+\Delta \boldsymbol{A}$ 及び $A_{0}-\Delta \boldsymbol{A}$ の $t$ と $u_{j}$ の関係がそれぞれ ocd 及び oef で表わされるものと する。このとき， $t=t_{0}^{(1)}$ において, 設計 $\boldsymbol{A}_{0}+\Delta \boldsymbol{A}$ で は $u_{j}<u_{j}^{(1)}$, 設計 $\boldsymbol{A}_{0}-\Delta \boldsymbol{A}$ では $u_{j}>u_{j}^{(1)}$ が成立し, $t=t_{0}^{(1)}$ での接線剛性行列は異なる值をとる。したがっ て, $t$ を $t_{0}^{(1)}$ で固定させたときの $u_{j}$ の設計感度係数は $\boldsymbol{A}$ の不連続な関数であり, $t=t_{0}^{(1)}$ での設計感度係数 は存在しないため,この方法では $u_{j}>u_{j}^{(1)}$ が成立する

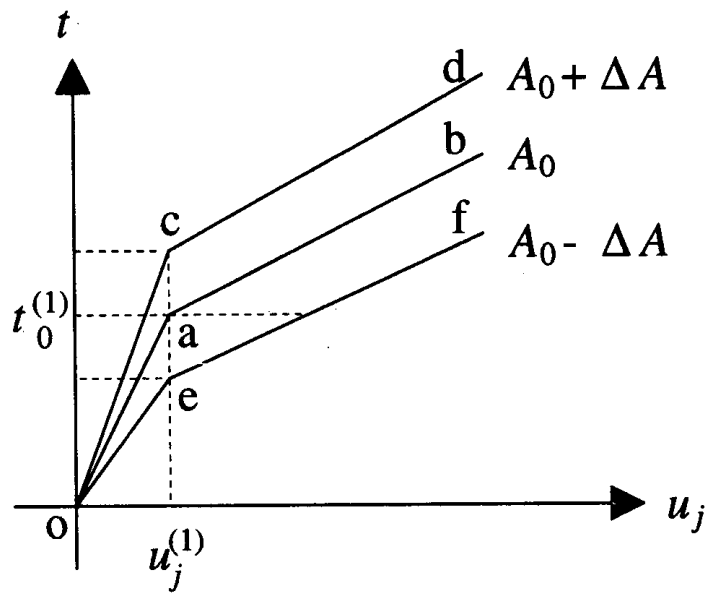

図 -2 設計変化にともなう時刻 - 変位関係の変化

領域での変位の設計感度係数を正確に求めることができ ない。

一方，明らかに， $u_{j}=u_{j}^{(1)}$ が成立するような時刻 での $u_{j}$ の值は $\boldsymbol{A}$ にかかわらず一定であり, その設計感 度係数は $\boldsymbol{A}$ の連続な関数である。ところが，このとき の $t$ の值 $t^{(1)}(\boldsymbol{A})$ は $\boldsymbol{A}$ の変化にともない変化する。ゆ えに, $u_{j}>u_{j}^{(1)}$ が成立する領域での変位の設計感度俰 数を求めるためには， $t^{(1)}(\boldsymbol{A})$ の設計感度係数を求める 必要がある。以上より，力学的特性が不連続に変化する 構造システムの設計感度解析では，境界時間 $t^{(j)}$ を正確 に求める必要があり，さらに，境界時間が設計変数 $\boldsymbol{A}$ の関数であることを考虑しなければならない $16 。$

変位の自由度を $f$ とすると, $(5 b),(7)$ の両辺を $A_{i}$ で微分することにより次の各式を得る。

$$
\sum_{k=1}^{f} \frac{\partial G_{j+1}}{\partial u_{k}} \frac{\partial u_{k}^{(j+1)}}{\partial A_{i}}=0
$$

$$
\begin{gathered}
\frac{\partial \boldsymbol{K}^{(j)}}{\partial A_{i}}\left(\boldsymbol{u}^{(j+1)}-\boldsymbol{u}^{(j)}\right)+\boldsymbol{K}^{(j)}\left(\frac{\partial \boldsymbol{u}^{(j+1)}}{\partial A_{i}}-\frac{\partial \boldsymbol{u}^{(j)}}{\partial A_{i}}\right) \\
=\left(\frac{\partial t^{(j+1)}}{\partial A_{i}}-\frac{\partial t^{(j)}}{\partial A_{i}}\right) \dot{\alpha}^{(j)} \boldsymbol{P}^{0}
\end{gathered}
$$

$\boldsymbol{u}^{(j)}, \boldsymbol{u}^{(j+1)}, \frac{\partial \boldsymbol{u}^{(j)}}{\partial A_{i}}, t^{(j)}, t^{(j+1)}$ 及び $\frac{\partial t^{(j)}}{\partial A_{i}}$ が既知のと き, (11)を用いて $\frac{\partial u^{(j+1)}}{\partial A_{i}} と \frac{\partial t^{(j+1)}}{\partial A_{i}}$ の間の次のよう な関係式を得る。

$$
\frac{\partial u^{(j+1)}}{\partial A_{i}}=d_{1} \frac{\partial t^{(j+1)}}{\partial A_{i}}+d_{2}
$$

ここで， $d_{1}$ 及び $d_{2}$ は既知のベクトルである。(12)を (10)に代入することにより $\frac{\partial t^{(j+1)}}{\partial A_{i}}$ が得られ，それを 再び (12)に用いることにより $\frac{\partial \boldsymbol{u}^{(j+1)}}{\partial A_{i}}$ が得られる。 ゆえに, $t=t^{(j+1)}$ での感度係数を求めるためには, 
$t^{(j)}$ 及び $t^{(j+1)}$ の正確な值が得られていなければならな w。

$t=t_{1}^{(j)}\left(t^{(j)} \leq t_{1}^{(j)} \leq t^{(j+1)}\right)$ において $\dot{\alpha}(t)$ が不連 続に変化するときには， $t_{1}^{(j)}$ は載荷条件として指定され た量であるから， $\frac{\partial t_{1}^{(j)}}{\partial A_{i}}=0$ であり，(11)のみを用い $\tau t=t_{1}^{(j)}$ での設計感度係数が得られる。以上より, 増 分応答解析と並行して感度解析を実行することができ る。

\section{4. 幾何学的非線形性を考慮した定式化}

幾何学的非線形性を updated Lagrangian 法 ${ }^{19}$ を用 いて定式化し，時刻 $t$ での応答量が得られているとき， $t+\Delta t$ での応答量を修正ニュートン法を用いて計算す る。

いま，簡単のため，第 $i$ 要素の応力 $\sigma_{i}$ 及びひずみ $\varepsilon_{i}$ が要素内で一定である場合を考える。これらの量が要素 内で一定でない場合にも，文献 16 と同様の定式化が可 能である。システム全体の応力ベクトル及びひずみべク

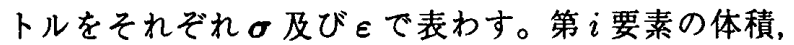
線形ひずみ - 変位関係行べクトル及び材端力ベクトルを それぞれ $V_{i}, \boldsymbol{B}_{L i}$ 及び $\boldsymbol{F}_{i}$ とする。このとき, 增分関係 の基礎式は，

$$
\begin{gathered}
\boldsymbol{F}_{i}^{(r)}={ }^{t} V_{i}{ }^{t} \boldsymbol{B}_{L i}^{T} \sigma_{i}^{(r)} \\
{ }^{t} \boldsymbol{K}\left(\boldsymbol{u}^{(r+1)}-\boldsymbol{u}^{(r)}\right)=\alpha(t+\Delta t) \boldsymbol{P}^{0}-\boldsymbol{F}^{(r)} \\
\varepsilon_{i}^{(r+1)}-\varepsilon_{i}^{(r)}={ }^{t} \boldsymbol{B}_{L i}\left(\boldsymbol{u}^{(r+1)}-\boldsymbol{u}^{(r)}\right) \\
\sigma_{i}^{(r+1)}-\sigma_{i}^{(r)}={ }^{t} D_{i}\left(\varepsilon_{i}^{(r+1)}-\varepsilon_{i}^{(r)}\right)
\end{gathered}
$$

のようになる。ここで（（）(r) は第 $r$ 繰り返しステップ での值, ${ }^{t}()$ は時刻 $t$ での值, $D_{i}$ は応力 - ひずみ関係 の接線係数であり，( $)^{T}$ はベクトルの転置を表わす。 これらの式を用いて修正ニュートン法に基づく繰り返 し計算により時刻 $t+\Delta t$ における応答量を求めるこ とができる。ここで, 応答量が十分収束した段階で, ${ }^{t+\Delta t} \boldsymbol{u}=\boldsymbol{u}^{(r)},{ }^{t+\Delta t} \sigma=\sigma^{(r)},{ }^{t+\Delta t} \varepsilon=\varepsilon^{(r)}$ である。

(13)-(16)を $\boldsymbol{A}$ で微分することにより, 設計感度係 数の増分関係式が得られる。例えば，(14)より

$$
\begin{gathered}
\left\{\frac{\partial^{t} \overline{\boldsymbol{K}}}{\partial A_{i}}+\sum_{j=1}^{f}\left(\frac{\partial^{t} \boldsymbol{K}}{\partial u_{j}} \frac{\partial^{t} u_{j}}{\partial A_{i}}\right)+\sum_{j=1}^{m}\left(\frac{\partial^{t} \boldsymbol{K}}{\partial \sigma_{j}} \frac{\partial^{t} \sigma_{j}}{\partial A_{i}}\right)\right\} \\
\times\left(\boldsymbol{u}^{(r+1)}-\boldsymbol{u}^{(r)}\right)+{ }^{t} \boldsymbol{K}\left(\frac{\partial \boldsymbol{u}^{(r+1)}}{\partial A_{i}}-\frac{\partial \boldsymbol{u}^{(r)}}{\partial A_{i}}\right) \\
=\frac{\partial \alpha}{\partial t} \boldsymbol{P}^{0} \frac{\partial^{t+\Delta t} t}{\partial A_{i}}-\frac{\partial \boldsymbol{F}^{(r)}}{\partial A_{i}}
\end{gathered}
$$

を得る。ここで， $m$ は要素数であり（）は $\boldsymbol{A}$ に関す る偏微分の過程において $\boldsymbol{u}$ を一定とすることを意味す る。
1 つの増分内での絽り返し計算の各ステップで, $\boldsymbol{u}^{(r)}, \frac{\partial^{t} \boldsymbol{u}}{\partial A_{i}}, \frac{\partial^{t} \boldsymbol{\sigma}}{\partial A_{i}}$ 及び $\frac{\partial \boldsymbol{u}^{(r)}}{\partial A_{i}}$ が得られているものとす る。次のステップで (14)を用いて $u^{(r+1)}$ が得られたと き, (17) を用いて $\frac{\partial u^{(r+1)}}{\partial A_{i}}$ と $\frac{\partial^{t+\Delta t} t}{\partial A_{i}}$ の間の次のよう な関係式を得る。

$$
\frac{\partial u^{(r+1)}}{\partial A_{i}}=b_{1}^{(r+1)} \frac{\partial^{t+\Delta t} t}{\partial A_{i}}+b_{2}^{(r+1)}
$$

ここで， $b_{1}^{(r+1)}$ 及び $b_{2}^{(r+1)}$ は既知のベクトルである。 繰り返し計算が収束したとき, $u^{(r+1)}={ }^{t+\Delta t} u$ とな $\eta$, 次の関係式を得る。

$$
\frac{\partial^{t+\Delta t} u}{\partial A_{i}}=b_{1} \frac{\partial^{t+\Delta t} t}{\partial A_{i}}+b_{2}
$$

ここで， $b_{1}$ 及び $b_{2}$ は既知のベクトルであり，(15) と (16)を $A_{i}$ で微分した式及び (18)を用いて, ${ }^{t+\Delta t} \boldsymbol{\sigma}$, ${ }^{t+\Delta t} \varepsilon$ に関しても同様の関係式が得られる。

時刻 $t+\Delta t$ でシステムの特性量が不連続に変化しな いときには。

$$
\frac{\partial^{t+\Delta t} t}{\partial A_{i}}=0
$$

であり，(19) 等を用いて ${ }^{t+\Delta t} u,{ }^{t+\Delta t} \sigma$ 及び ${ }^{t+\Delta t} \varepsilon$ の $A_{i}$ に関する感度係数を求めることができる。一方, $t+\Delta t$ でシステムの特性量が不連続に変化する場合に は， $(5 a)$ を $A_{i}$ で微分して $t=t+\Delta t$ で評価した式

$$
\sum_{k=1}^{f} \frac{\partial G_{j}}{\partial u_{k}} \frac{\partial^{t+\Delta t} u_{k}}{\partial A_{i}}=0
$$

に(19)を代入することにより， $\frac{\partial^{t+\Delta t} t}{\partial A_{i}}$ が得られ，そ の值を $(19)$ 及び $\sigma^{(r)}, \epsilon^{(r)}$ に関する同様の式に代入す ることにより，応答量の設計感度係数が得られる。以上 より，繰り返し計算に基づき，応答解析及び設計感度解 析を並行して実行することができる。

\section{5. 例題}

本論で提示した手法の有効性を明らかにするため, 変位拘束を有する弾性トラス, 弾塑性せん断型構造物及 び弾塑性平面トラスに対して設計感度解析を行ない, $\mathrm{IDESIGN}^{20}$ を用いて最適設計解を求めた。

\section{变位拘束を有する弾性トラス}

接触問題の簡単な例として，図 3 のような変位拘束 を受けるトラスに対して設計感度解析を行なった。ここ で, 載荷条件は $P=t P^{0}\left(P^{0}=9.8 \mathrm{~N}\right)$ の単調載荷であ り, $W=2 \mathrm{~m}, H=2 \mathrm{~m}, D=1 \mathrm{~cm}$ である。また, 弾 性係数 $E$ は $205.8 \mathrm{GPa}$ であり，簡単なモデルによる手 法の説明のため, 幾何学的非線形性及び部材の降伏は考 えないものとする。

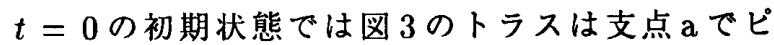
ン支持，支点 $\mathrm{b}$ でローラー支持されており，部材断 


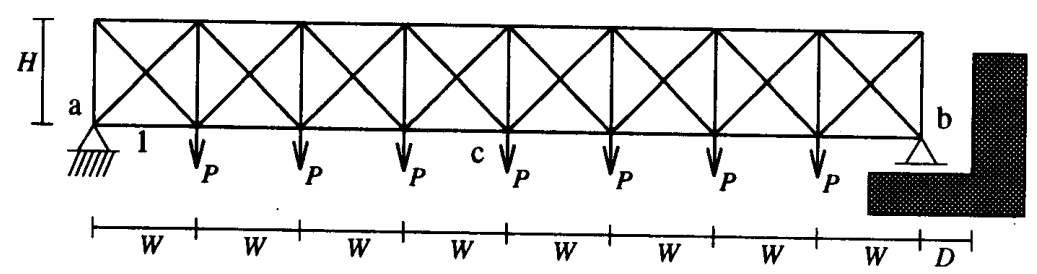

図 -3 変位拘束を有する 41 部材平面トラス

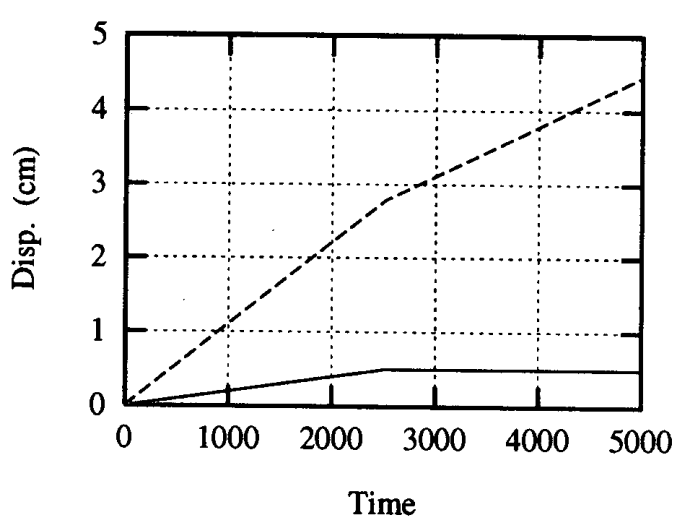

図-4 41 部材平面トラスの $t$ と変位の関係

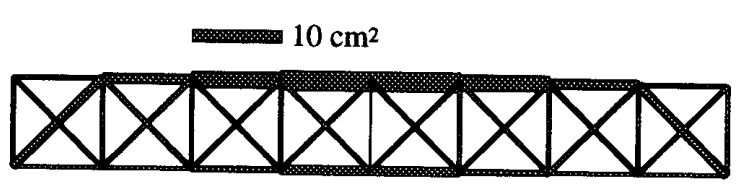

図-5 41 部材平面トラスの最適設計解

面積を $A_{i} \equiv 10.0 \mathrm{~cm}^{2}$ としたとき， $t$ を増加させると $t=t^{(1)}=2516.5$ で支点 $\mathrm{b}$ の水平方向変位 $u_{b}$ が上限值 $\bar{u}_{b}=1.0 \mathrm{~cm}$ に達し, 以後支点 $\mathrm{b}$ での支持条件はピン 支持となる。この場合, 明らかに剛性行列は $t=t^{(1)}$ でそのサイズが変化する。 $t$ を 5000.0 まで増加させた ときの $u_{b}$ 及び節点 $\mathrm{c}$ の載荷方向变位 $u_{c}$ の変化をそれ ぞれ図 4 の実線及び点線で示す。 $t=5000.0$ において $u_{c}=4.4606 \mathrm{~cm}$ であり, 本論で提示した感度解析法を 用いて得られた第 1 部材の断面積に関する設計感度係 数 $\partial u_{c} / \partial A_{1}$ の值は $-0.12320 \mathrm{~cm}^{-1}$ である。この值は $\Delta A_{1}=0.001 \mathrm{~cm}^{2}$ とした中央差分法で得られた設計感 度係数と 5 桁の精度で一致している。

$A_{1}>10.0 \mathrm{~cm}^{2}$ のトラスでは $t=t^{(1)}$ で $u_{b}$ は $\bar{u}_{b}$ に 達しておらず， $A_{1}<10.0 \mathrm{~cm}^{2}$ では $t$ が $t^{(1)}$ に達する までに $u_{b}=\bar{u}_{b}$ となる。したがって, $t=t^{(1)}$ での $u_{b}$ の感度係数は $\boldsymbol{A}$ の不連続な関数であり, $t=5000.0$ で の応答量の設計感度係数を精度良く求めるためには, $u_{b}=\bar{u}_{b}$ となる時刻が $\boldsymbol{A}$ の関数であることを撖密に考 慮する必要がある。

このトラスに対してIDESIGNを用いて最適設計解 を求めた。ここで, コスト関数は全部材体積であり, 変

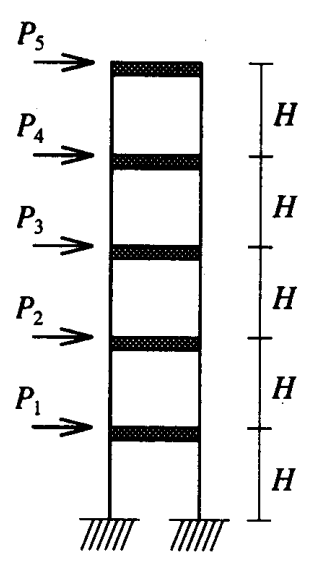

図一6 5 層せん断型構造物

位の絶対値の上限値を $5.0 \mathrm{~cm}$ とする。また, 全部材に 対して最小断面積制限值 $3.0 \mathrm{~cm}^{2}$ を与える。最適設計解 を図 5 に示す。この図より，中央付近の上弦材の断面積 を大きくすることが有効であることがかかる。最適設計 解におけるコスト関数值は $2.3129 \times 10^{4} \mathrm{~cm}^{3}$ であり， 全部材を一定值として最大変位が指定上限值に一致する 設計解での值の $27.217 \%$ となっている。

\section{繰り返し載荷を受ける弾塑性せん断型構造物}

図 6 のような 5 層せん断型構造物に対して設計感度 解析及び最適設計を行なった。ここで，H=4mで ある。載荷条件は図 7 のような繰り返し載荷とする。 ここで, $t=1,3,5,7$ における荷重係数 $\alpha(t)$ の值はそ れぞれ $5000.0,-5200.0,5200.0,-5400.0$ である。ま た，基準荷重 $P_{i}^{0}$ は耐震設計において通常用いられる比 率の分布とし，ここでは，1層から5 層に対してそれぞ れ $0.49115,0.67966,0.88428,1.1305,1.8144 \mathrm{kN}$ とす る。層間変位と層せん断力の関保はバイリニアとし，既 存の構造物のデータから判断して, 層間変形角 0.007 で 第 1 分枝から第 2 分枝へ移行するものとする。さらに, 第 2 勾配の第 1 勾配に対する比は 0.7 とする。

コスト関数は，層剛性の和とし，層間変形角の絶対 値の上限值を 0.01(Case 2-1) 及び0.015(Case 2-2)の 場合について最適設計解を求めた。 2 つ最適設計解の 全ての層に扔いて，層間変形角の制約条件は等号で満 たされており，2～ 5 層の剛性の第 1 層剛性に対する 比は Case 2-1, Case 2-2 ともに同一であり，それぞれ $0.90177,0.76584,0.58898,0.36288$ である。Case 2-1 での第 1 層の層間剛性は $741.751 \mathrm{kN} / \mathrm{m}$ である。Case 2-2における最適コスト関数值の Case 2-1 での值に対 する比は 0.7222 であり, 層間変位の上限值を $50 \%$ 増加 させることにより，コスト関数値は $27.78 \%$ 減少してい る。

\section{繰り返し載荷を受ける弾塑性トラス}

図 8 のような平面トラスに対し, 繰り返し荷重を作 用させて，最適設計を行なった。ここで，図7のよう 


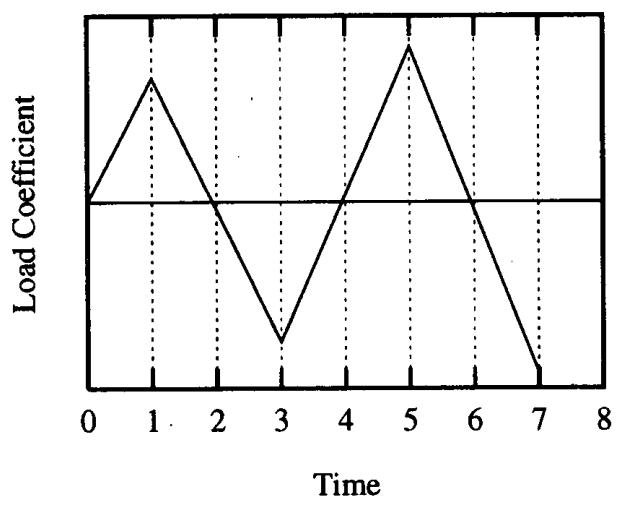

図 -7 荷重係数と $t$ の関係

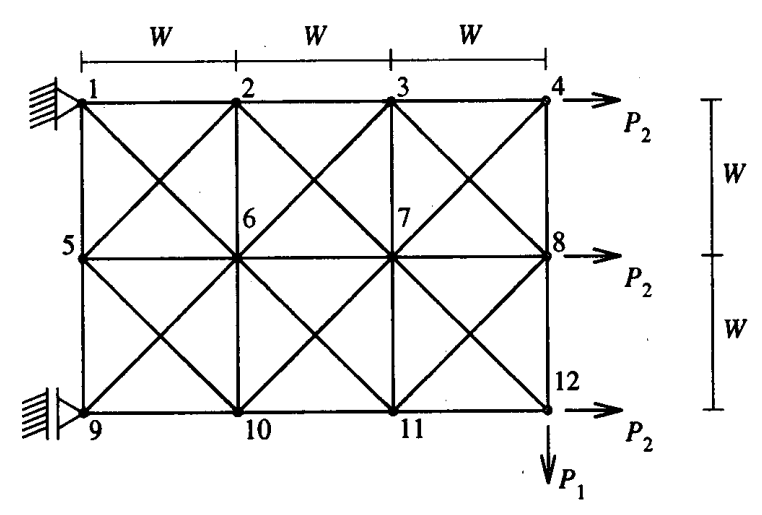

図-8 29 部材平面トラス

な荷重係数を与え, $t=1,3,5,7$ における $\alpha(t)$ の值は それぞれ $12000.0,-14000.0,14000.0,-16000.0$ であ る。図 8 において $W=2.0 \mathrm{~m}$ であり, 部材の応力 - ひ ずみ関係はバイリニアとし，その接線係数は降伏前は

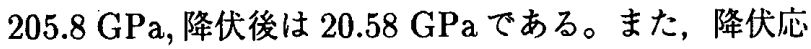
力は $2352.0 \mathrm{MPa}$ とし，簡単のため部材の座屈は考えな い。さらに, 全部材に対して最小断面積制限値 $4.0 \mathrm{~cm}^{2}$ を与る。

$P_{1}^{0}=P_{2}^{0}=9.8 \mathrm{kN}$, ひずみの絶対値の上限值を $1.4 \times 10^{-3}$ とした Case 3-1 について設計感度解析及び 最適設計を行なった。幾何学的非線形性を考慮した場 合の最適設計解を図 9 に示す。ここで，全部材体積は $3218.2 \mathrm{~cm}^{3}$ であり, 幾何学的非線形性を考慮しない場 合には $3216.4 \mathrm{~cm}^{3}$ である。したがって，この例では幾 何学的非線形性の影響はほとんどみられない。ひずみの 絶対値の上限值を $3.0 \times 10^{-3}$ としたときの最適設計解 における断面積分布は図 9 とほほ同様である。幾何学的 非線形性を考虑した場合の全部材体積は $3077.5 \mathrm{~cm}^{3}$ で あり，ひずみの許容值が 2.1429 倍となったのにもかか わらず, 全部材体積はほとんど変化していない。このこ とは,ひずみの許容值の変化に比較して, 応力の許容値

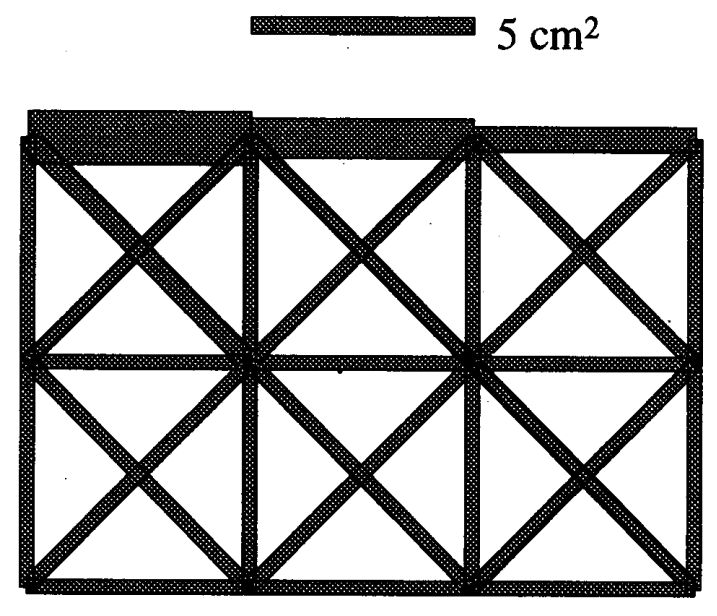

図-929 部材平面トラスの最適設計解 (Case 3-1)

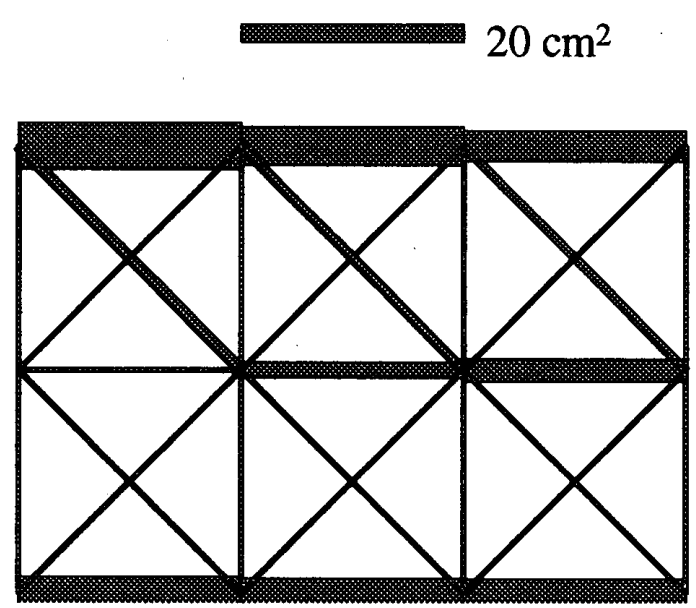

図-1029 部材平面トラスの最適設計解 (Case 3-2)

の変化は微小であることが原因であるものと考えられ る。

次に, $P_{1}^{0}=9.8 \mathrm{kN}, P_{2}^{0}=49.0 \mathrm{kN}$ とし，ひずみの 絶対值の上限値を $1.4 \times 10^{-3}$ としたとき(Case 3-2)の 幾何学的非線形性を考慮した場合の最適設計解を図 10 に示す。ここで, 全部材体積は $7899.7 \mathrm{~cm}^{3}$ であり, 幾 何学的非線形性を考慮しない場合には $7833.5 \mathrm{~cm}^{3}$ であ る。また, ひずみの絶対值は全ての部材において $t=7$ で最大となっている。この例では，大きい断面積値をと る部材におけるひずみの最大值が負であることから，幾 何学的非線形性は剛性を低下させる方向へ影響している ものと考えられる。

\section{6. 結論}

本論で得られた成果は以下のとおりである。

(1) 力学的特性が不連続に変化する構造システムに対 して, 変位等の応答量の, 設計変数に関する感度俰数を 求めるための一般的手法を提示した。本手法では, 特性 
が不連続に変化するパラメター值 (境界時間) が設計変 数に依存することを厳密に考慮するため, 精度の良い設 計感度係数を求めることができる。

（2）（1）の手法を変位拘束を有する弾性トラス, 弾塑 性せん断型構造物及び繰り返し載荷を受ける弾塑性トラ スに対して適用し，その有効性を明らかにした。さら に, 沉用最適化プログラムを用いて最適設計解を求め, その特性を明らかにした。本手法をより一般的な接触問 題及び片側応力問題に適用するためには，文献 4 と同様 の手法を用いて幾何学的非線形性を導入することが必要 である。

（3）繰り返し載荷を受ける弾塑性トラスに対して幾何 学的非線形性を考虑して最適設計解を求めた。その結 果, 幾何学的非線形性の最適設計解への影響は荷重条件 に依存すること及び，ひずみの上限值の変化は，最適設 計解に対してほとんど影響を及ほさないことを示した。

\section{参考文献}

1) J.S. Arora: Introduction to Optimum Design, McGraw-Hill, New York, 1989.

2) E.J. Haug, K.K. Choi and V. Komkov: Design Sensitivity Analysis of Structural Systems, Academic Press, New York, 1986.

3）山川宏: 最適化デザイン, 倍風館, 1993.

4) 鈴木敏郎, 小河利行, 末岡利之, 小笠原朋隆: ペナルティー 法による薄肉弾性体の接触問題の有限要素解析, 日本建築 学会構造系論文報告集, No.423, pp89-96, 1991.

5) 半谷裕彦: 片側応力問題の変分不等式とポテンシャル関数, 生産研究, Vol.38, pp62-65, 1986.

6) C.Y. Sheu and W. Prager: Optimal plastic design of circular and annular sandwich plates with piecewise constant cross-section, J. Mech. Phys. Solids, Vol.17, pp11-16, 1969.

7) I. Kaneko and G. Maier: Optimal design of plastic structures under displacement constraints, Comp. Meth. Appl. Mech. Engng., Vol.27, pp369-391, 1981.

8) M.P. Bendsøe and J. Sokolowski: Sensitivity analysis and optimization of elastic-plastic structures, Engineering Optimization, Vol.11, pp31-38, 1987.

9) M.P. Bendsøe and J. Sokolowski: Design sensitivity analysis of elastic-plastic analysis problem, Mech. Struct. Mach., Vol.16, pp81-102, 1988.
10) J.J. Tsay and J.S. Arora: Nonlinear structural design sensitivity analysis for path dependent problems, Part 1: General theory, Comp. Meth. Appl. Mech. Engng., Vol.81, pp183-228, 1990.

11) J.J. Tsay, J.E.B. Cardoso and J.S. Arora: Nonlinear structural design sensitivity analysis for path dependent problems, Part 2: Analytical examples, Comp. Meth. Appl. Mech. Engng., Vol.81, pp183$228,1990$.

12) J.J. Tsay and J.S. Arora: Optimum design of nonlinear structures with path delendent response, Structural Optimization, Vol.1, pp203-213, 1989.

13) C.A. Vidal, H.-S. Lee and R.B. Haber: The consistent tangent operator for design sensitivity analysis of history-dependent response, Comp. Systems in Engng., Vol.2, pp509-523, 1991.

14) M.P. Bendsøe, N. Olhoff and J. Sokolowski: Sensitivity analysis of problems of elasticity with unilateral constraints, Mech. Struct. Mach. Vol.13, pp201-222, 1985.

15) M.P. Bendsøe and J. Sokolowski: Sensitivity analysis and optimal design of elastic plates with unilateral point support, Mech. Struct. Mach. Vol.15, pp383$393,1987$.

16) M. Ohsaki and J.S. Arora: Design sensitivity analysis of elastoplastic structures, Int J. Num. Meth. Engng., Vol.37, pp737-762, 1994.

17）矢川 元基, ニューラルネットワーク, 倍風館, 1992.

18) C.C. Wu and J.S. Arora: Design sensitivity analysis and optimization of nonlinear structural response using incremental procedure, AIAA J., Vol.25, pp1118-1125, 1987.

19) K.J. Bathe, E. Ramm and E.J. Wilson: Finite element formulations for large deformation dynamic analysis, Int. J. Num. Meth. Engng., Vol.9, pp353$386,1974$.

20) J.S. Arora and C.H. Tseng: IDESIGN User's Manual Ver. 3.5, Optimal Design Laboratory, The University of lowa, 1987.

(1994 年 6 月 7 日原稿受理, 1994 年 10 月 3 日採用決定) 